\title{
ECONOMIC EVALUATION OF TRANSPORTATION PROJECTS BASED ON DIFFERENT FINANCING METHODS: AT THE FRAMEWORK OF FINANCIAL COMPUTABLE GENERAL EQUILIBRIUM MODEL
}

\author{
DOI: 10.17261/Pressacademia.2020.1359 \\ PAP- V.12-2020(23)-p.87-88
}

\section{Metin Piskin}

Istanbul S. Zaim University, Department of Economics, Istanbul, Turkey. metin.piskin@izu.edu.tr, ORCID: 0000-0002-1170-2273

\section{To cite this document}

Piskin, M. (2020). Economic evaluation of transportation projects based on different financing methods: at the framework of financial computable general equilibrium model. PressAcademia Procedia (PAP), V.12, p.87-88.

Permanent link to this document: http://doi.org/10.17261/Pressacademia.2020.1359

Copyright: Published by PressAcademia and limited licensed re-use rights only.

\section{ABSTRACT}

Purpose- The purpose of this study is to develop a first fully functional Turkish Financial Computable General Equilibrium (FCGE) model that analyzes the economic impacts of infrastructure investment projects under different financing options. We examine three alterantive financing methods, i.e., public financing with tax revenues and government bonds, public financing with region specific tax policy and private financing.

Methodology- The study employs Financial Computable General Equilibrium (FCGE) model. The FCGE model integrates the real economy with the financial one, and traces the flows of financial and real resources among economic agents at the same time. Computable General Equilibrium (CGE) models typically are comparative static equilibrium models of interregional trade and location based in microeconomics, using utility and production functions with substitution between inputs. The transport system enters the spatial economy through the costs of transport services. Transport sub models are applied to feed CGE models with cost changes in the transport sector as a result of policy measures. Our model is composed of a multi-regional financial CGE model and a transport network model. Turkish Multi Regional Computable General Equilibrium model constitutes of 11 regions. The model includes ten producers, one regional household, one national (or central) government and the rest of the world.

Findings- The model is designed to analyze the economic effects of fiscal policies such as the transportation investment expenditures and alternative financing approaches on economic growth and welfare. It is possible to estimate growth and distributional effects of each project based on the financing method once the information on the investment expenditures, the construction location and the changes in the accessibility generated by the project are injected into the FCGE model. As a first attempt, we builded a Financial Social Accounting Matrix (SAM) for Turkey that FCGE models need, containing the details of financial institutions and transaction of agents' assets and liabilities. The model specifies the behaviours of ten different sectors, one household, a central government, and the rest of the world. The model is designed to analyze the impacts of highway development with different financing strategies. We examine three alterantive financing methods: it can (a) public financing with tax revenues and government bonds, (b) public financing with region specific tax policy or (c) private financing.

Conclusion- The main contribution of this research is to develop a first fully functional FCGE model to analyze the economic impacts of the infrastructure investment projects and their financing options on growth and welfare in Turkish economy. We develop a first fully functional Turkish Financial Computable General Equilibrium (FCGE) model that analyzes the economic impacts of infrastructure investment projects under different financing options. There are a number of ways to finance highway infrastructure investment: fuel taxes, user fees, trust funds etc. This Financial CGE model is expected to assess the consistency of highway investment programs under different financing options, so the government can make a decision on an approval for the project based according to their benefits and costs on national level.

Keywords: Social accounting matrix, fiscal policy, project analysis, computable general equilibrium models, transportation investments. JEL Codes: E16, E62, C68 


\section{REFERENCES}

Kim, E., Hewings, G. J. D., Amir, h. (2017). Economic evaluation of transportation projects: An application of Financial Computable General Equilibrium model. Research in Transportation Economics, Vol.61: 44-55.

Kim, E., Kim, H. S., Hewings, G. J. D. (2011). An Application of the Integrated Transport Network-Multi-regional CGE Model: An Impact Analysis of Government-Financed Highway Projects. Journal of Transport Economics and Policy, Vol. 45: 223-245.

Kim, E., Bae, Y. (2015). Economic Contribution of the Private Sector on Financing and Operation of a Highway: Financial Computable General Equilibrium. Journal of Transport Economics and Policy, Vol. 49: 397-414.

Chen, Z., Daito, N., Gifford, J. L. (2017). Socioeconomic impacts of transportation public-private partnerships: A dynamic CGE assessment. Journal of Transport Policy. Vol. 58:80-87.

Kim, E., Samudro, Y. N. (2016). Structural Path Analysis of Fuel Subsidy and Road Investment Policies. Journal of Transport Research, 23(4), 119-143. 